\title{
Ex vivo effects of flavonoïds extracted from Artemisia herba alba on cytokines and nitric oxide production in Algerian patients with Adamantiades-Behçet's disease
}

Djamel Messaoudene ${ }^{1,2^{*}}$, Houda Belguendouz ${ }^{1}$, Mohamed Laid Ahmedi ${ }^{1}$, Tarek Benabdekader ${ }^{2}$, Fifi Otmani ${ }^{3}$, Malika Terahi ${ }^{4}$, Pierre Youinou ${ }^{5}$ and Chafia Touil-boukoffa ${ }^{1}$

\begin{abstract}
Background: Adamantiades-Behçet's disease (ABD) is a chronic multisystemic inflammation with unknown pathophysiology. This disorder is associated with a dysregulation of the cytokine network that hyperactivates neutrophils and macrophages. In this study, we investigate the modulatory effects of flavonoïd compounds extracted from Algerian medicinal plant Artemisia herba alba on Th1 and Th2 cytokines and nitric oxide production.

Methods: The modulatory effects of flavonoïds extracted from Artemisia herba alba on cytokines and nitric oxide production by peripheral blood mononuclear cells isolated from Algerian ABD patients and healthy controls were respectively measured by means of ELISA assays and Griess modified method.

Results: Our results show that flavonoïds significantly reduce the production of interleukin-12, the key effector of T helper 1 (Th1) cells and nitric oxide in a dose-dependent manner in Adamantiades-Behçet's disease. In contrast, the production of IL-4, the key marker of Th2 cells was increased.

Conclusion: This study suggests that in vitro supplementation with flavonoïds extracted from Artemisia herba alba could have potential immuno-modulatory effects characterised by a down-regulation and up-regulation of Th1 and Th2 cytokines, respectively. Moreover, flavonoïds may prevent nitric oxide induced damages.
\end{abstract}

Keywords: Adamantiades-Beh?ç?et?'?s disease, Artemisia herba alba, Flavono?i?ds, Immunomodulation, IL-4, IL-12, nitric oxide

\section{Background}

Adamantiades-Behest's disease (ABD) is an inflammatory multisystemic disorder involving mucocutaneous, ocular, arthritic, vascular and central nervous systems. It is most prevalent in the Mediterranean countries, including Algeria, and along the Silk Route. Various factors have been reported contribute to the development of the lesions associated to the disease such as, the genetic susceptibility, environmental factors, anomalies in the inflammatory responses and immune system dysfunction $[1,2]$.

\footnotetext{
* Correspondence: mdjiji68@hotmail.com

${ }^{1}$ Laboratoire de Biologie Cellulaire et Moléculaire (LBCM), FSB, USTHB.

Université de Bab-Ezzouar. BP32, 16111. Algiers, Algeria

Full list of author information is available at the end of the article
}

In response to antigens, mediators such as cytokines and chemokines are produced by various cell types, either hematopoietic or non hematopoietic, These mediators orchestrate the immune response by recruitment and activation of different cell types. The involvement of cytokines and chemokines in ABD pathogenesis is reflected by the increase of their concentrations in sera of patients with $\mathrm{ABD}$ and some of these mediators correlate with the clinical activity of the disease. Many studies have indeed reported high sera levels of tumornecrosis factor (TNF)- $\alpha$, TNF receptor, soluble IL-2R and multiple interleukins (IL-1, IL-6, IL-8, IL-12) [3]. Among them, IL-12 is known to play a major role in the polarization of $\mathrm{T}$ helper (Th)1-type cells and sera IL-12 and interferon (IFN)- $\gamma$ levels are elevated in ABD

\section{C) Biomed Central}


[4,5]. Moreover, the increase of IL-12 levels in the peripheral blood mononuclear cells (PBMCs) of patients with ABD have been described [6]. This cytokine is responsible for the development of a Th-1 type response and may play a crucial role in the pathogenesis of the disease [7]. However, other investigators have reported increased sera levels of Th2-type cytokines, including IL-4, IL-10, and IL-13 in ABD patients [8], suggesting disturbed cytokines production in ABD. Such dysregulation in cytokine release contributes to the regulation of several enzymes such as the inducible nitric oxide (NO) synthase (iNOS). The function of NO has been delineated in a variety of inflammatory processes. An excess of NO production or peroxynitrite radical could indeed cause oxidative damages through its action on membrane lipids, DNA, proteins and lipoproteins $[9,10]$. These reactions have functional consequences which may be deleterious $[11,12]$. The large amounts of NO production have been shown to be correlated with pathophysiology in a plethora of diseases and inflammation processes, such as bowel inflammatory disease [13] and Adamantiades-Behçet's disease [14]. Consequently, the development of molecules aimed to prevent the overproduction of NO constitutes an interesting area of research of a new treatment of chronic inflammatory diseases [15-18].

In the absence of curative treatments in $\mathrm{ABD}$, some patients adopt alternative medicine to avoid the irreversible effects of corticotherapy. For example, Artemisia herba-alba (Asteraceae) known as "desert wormwood", or "Chih" as it is commonly named in Algeria is largely consumed. Artemisia herba-alba is a plant of the Lamiacaea family, growing in arid and semi-arid climates and it is widely used in folk medicine in different countries. It is characteristic of the steppes and deserts of the Middle East, North Africa, Spain and North western Himalayas [19]. Artemisia has been a productive genus in the search for new biologically active compounds. Phytochemical investigations have proven that this genus is rich in terpenoids, flavonoïds, coumarins, acetylenes, caffeoylquinic acids and sterols and it was shown that Artemisia has multiple beneficial bioactivities: antimalarial, anti-viral, anti-tumor, anti-pyretic, anti-hemorrhagic, anti-coagulant, anti-anginal, anti-oxidant, antihepatitis, anti-ulcerogenic, antispasmodic and anti-complementary activities [20-26].

The flavonoïds detected in Artemisia herba alba show also a structural diversity starting from common flavonoïds (flavones glycosides and favonols) to the methyled flavonoïds which is very unusual $[27,28]$. Some beneficial bioactivities of flavonoïds have been proved, such as antibacterial, anticarcinogenic, antioxidant, antimutagenic, anti-inflammatory, activities and immunomodulatory activities [29-34]
In the present work was investigated the effect of the flavonoïds extracted from the medicinal plant A. herba alba on the production of IL-12 and IL- 4 and we examined nitric oxide production as a marker of the inflammatory response in the PBMC of patients with Adamantiades-Behçet's disease (ABD). Artemisia herba $a l b a$ may represent an alternative therapy for Algerian patients with $\mathrm{ABD}$.

\section{Methods}

\section{Patients and controls}

Samples from Twenty patients (8 men and 12 women) were obtained from the ophthalmology and internal medicine service, Bab El Oued Hospital and Algiers Medicinal University Hospital (Mustapha Bacha), respectively. Patients with ABD (females and males) were tested during the clinically active stage. The mean age of the active stage was 38.43 years (20-58 years) and the mean duration of the disease was 7.69 years (1-18 years). ABD was diagnosed according to the criteria defined by the international study group for ABD set up in 1990 [35]. All ABD patients were showing the major symptoms including uveitis, aphtosis, articular and neurological manifestations and they had been treated with colchicine and other oral medication (methylprednisolon, cyclophosphamid). Clinical characteristics of ABD patients were given in Table 1. Each patient has given a written informal consent for the study required by the ethic committee of the national agency of research development in health (ANDRS) which supported our project. The healthy controls consisted of 8 males and 12 females (mean age 39.7 years, range 20-59).

\section{Plant materials and flavonoïds extraction}

The flowering aerial parts of A. herba alba were collected from Djalfa region (city of south Algeria). The plant was then identified in the department of botany of the national institute of agronomy in Algeria. Flavonoïds were extracted according to the extraction method described previously by Paris and Nothis [36]. Briefly, 20 $\mathrm{g}$ of the pulverized plant material were macerated for 24 hours in methano-containing water $(7: 3)$. The filtrate was evaporated at $40^{\circ} \mathrm{C}$ to get completely rid of the solvent mixture. The solid extract was then submitted three times to $50 \mathrm{ml}$ n-butanol to collect the flavonoïds mixture. The solution was filtrated and evaporated at $40^{\circ} \mathrm{C}$ and then dissolved in water. The extracts were kept frozen $\left(-20^{\circ} \mathrm{C}\right)$ until used.

\section{PBMC cultures}

PBMCs were separated by centrifugation on Ficoll-hypaque gradient and washed twice in phosphate-buffered saline, $\mathrm{pH}$ 7.2. Cells were then harvested for test viability with trypan blue then resuspended in complete medium 
Table 1 Characteristics of active stage of Adamantiades-Behçet's disease patients (number mean \pm standard deviation, percentage)

\begin{tabular}{ll}
\hline Sex $(M / F)$ & $8 / 12$ \\
Age at disease onset (mean years +SD) & $34 \pm 10$ \\
Follow-up duration (years) & $7.69 \pm 8.5(1-18)$ \\
Uveitis & $7 / 20(35 \%)$ \\
Aphtosis & $6 / 20(30 \%)$ \\
Articular symptoms & $4 / 20(20 \%)$ \\
NeuroBehçet & $3 / 20(15 \%)$ \\
Treatments & Colchicine, methylprednisolon, cyclophosphamid \\
\hline
\end{tabular}

consisting of RPMI-1640 supplemented with $10 \%$ fetalcalf serum, 100 units $/ \mathrm{ml}$ penicillin and $100 \mu \mathrm{g} / \mathrm{ml}$ streptomycin.

To test cytokines and NO production, PBMC of ABD patients were treated with different concentrations of flavonoïds $(5,10,20,30,40$ or $50 \mu \mathrm{g} / \mathrm{mL})$ and incubated at $37^{\circ} \mathrm{C}$ and $5 \% \mathrm{CO}_{2}$ during 20 hours. Cells were then harvested for test viability and cultures supernatants were conserved at $-70^{\circ} \mathrm{C}$ for cytokines and $\mathrm{NO}$ measurements.

For healthy controls and ABD control (before flavonoïds treatment), PBMCs were pre-activated with phytohaemagglutinin (PHA) $(5 \mu \mathrm{g} / \mathrm{mL})$ in $5 \% \mathrm{CO}_{2}$ at $37^{\circ} \mathrm{C}$ during 20 hours to mimic the pre-activated stage of ABD cells.

\section{Cytokine analysis}

The concentrations of IL-12 and IL-4 were measured using enzyme linked immunosorbent assays (ELISA) according to manufacture's instructions (Amersham Pharmacia, England). Supernatants samples were added to appropriate wells of a microtiter-plate coated with a specific monoclonal antibody (mAb) against distinct epitopes of IL-12 or IL-4. After incubation for 2 hours, 50 $\mu \mathrm{L}$ of anti IL-12 mAb or anti IL- $4 \mathrm{mAb}$ conjugated to horseradish-peroxidase were added. The coloration reaction was read at $540 \mathrm{~nm}$. A standard curve was used to quantify supernatants levels of IL-12 and IL-4. The lowest level of sensitivity was $10 \mathrm{pg} / \mathrm{mL}$ for IL-12 and $5 \mathrm{pg} /$ $\mathrm{mL}$ for IL-4 of the cytokine.

\section{NO production by PBMCs}

PBMCs of patients and NCs were cultured at $5 \times 10^{6}$ cells/uL (100 uL/well) with $100 \mathrm{uL}$ of flavonoïds extract $(5,10,20,30,40$ or $50 \mu \mathrm{g} / \mathrm{mL})$ in 96 -well microtiterplates in a humidified incubator at $37^{\circ} \mathrm{C}$ and $5 \% \mathrm{CO}_{2}$ for 20 hours. Then NO production was assessed by the determination of the final products of $\mathrm{NO}$ oxidation. After reduction of nitrates $\left(\mathrm{NO}_{3}^{-}\right)$by nitrate reductase containing Pseudomonas oleoveorans Bacteria (ATCC, 8062) containing nitrate reductase, total nitrite (nitrite $\mathrm{NO}_{2}^{-}+$nitrate $\mathrm{NO}_{3}^{-}$) was determined with the spectrophotometrically Griess reaction as described by Amri et al [37]. Griess reagent 2\% p-amminobenzene sulphanamide in 5\% phosphoric acid and $0.2 \% \mathrm{~N}$ (1naphhtiyl) ethylene diamine (dihydrochlorid) was added to the sample. The mixture was incubated for $10 \mathrm{~min}$ utes at room temperature and the absorbance at 543 $\mathrm{nm}$ was read by spectrophotometer. The concentration was determined with reference to a sodium nitrites $\mathrm{NaNO}_{2}$ standard $(0-200 \mu \mathrm{mol} / \mathrm{mL})$ curve. Results were expressed as $\mu \mathrm{M}$ of nitrites in supernatants of PBMC cultures.

\section{Statistical analysis}

Results were expressed as the mean \pm standard deviation. Statistical differences were assessed using one-way ANOVA with posthoc test of the means according to Tukey's method. In single mean comparisons, Student's t-test was used to test the data and considered statistically significant for $P$ values $<0.05$. Results and graphics were performed with STATISTCA v. 5 software under windows.

\section{Results}

In vitro production of cytokine during the active stage of ABD

To quantify the spontaneous production of IL-12, IL-4 and NO during the active stage, we measured their levels in cultures supernatants of PBMC of ABD patients compared with NCs. As shown in Figure 1A, IL-12 levels in ABD patients were higher than in NCs: $1134.02 \pm 83.70$ versus $583.02 \pm 98.44 \mathrm{pg} / \mathrm{mL}, \mathrm{p}<0.05$. The stimulation with flavonoïds showed an increased level of IL-12 in both ABD patients and NCs (1358.63 \pm 118.41 versus $1143.27 \pm 104.73 \mathrm{pg} / \mathrm{mL}$, respectively). However, we did not observe any significant difference $(\mathrm{P}>0.05)$. In the absence of PHA stimulation, PBMC from ABD patients showed similar level of IL-12 $(1134.03 \pm 83.69)$ compared to PBMC from controls after stimulation with PHA $(\mathrm{p}<0.85)$. This result prompted us to use for the same plant extract treatment experiment the preactivated PBMC from controls and those from $\mathrm{ABD}$ patients without activation with PHA. 


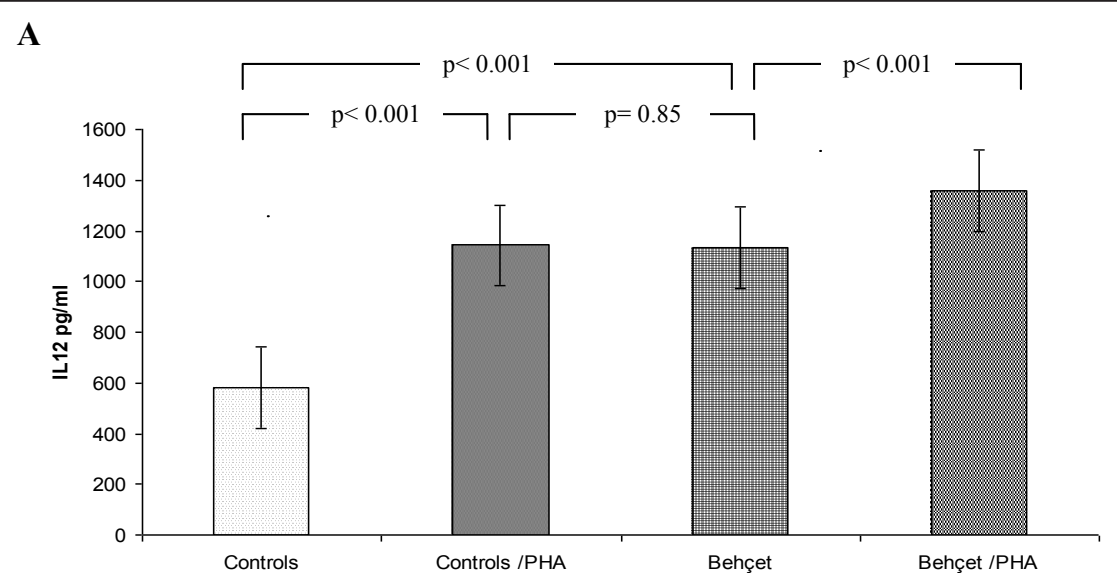

B

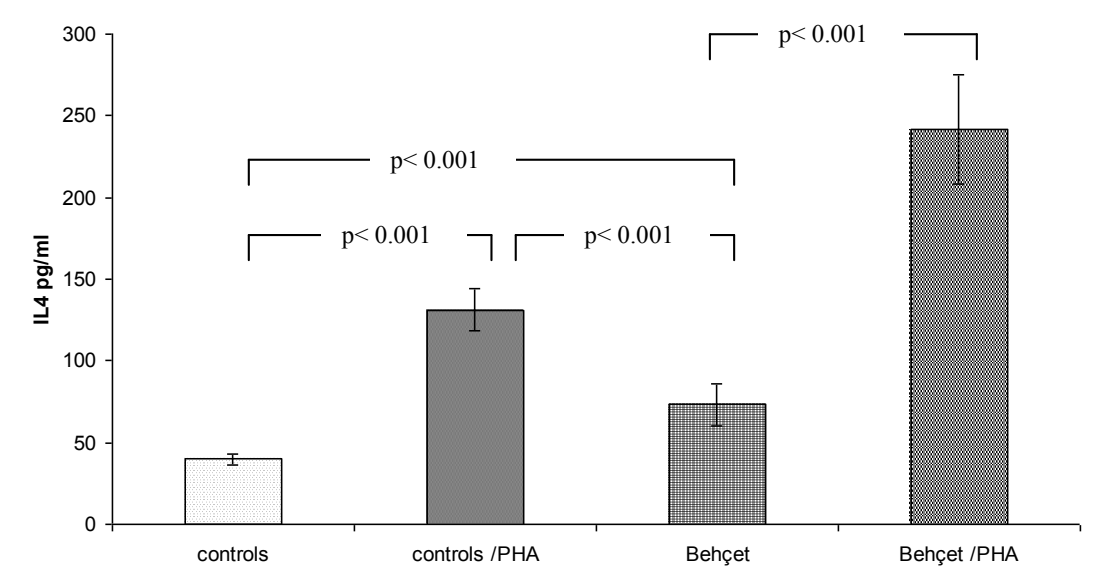

C

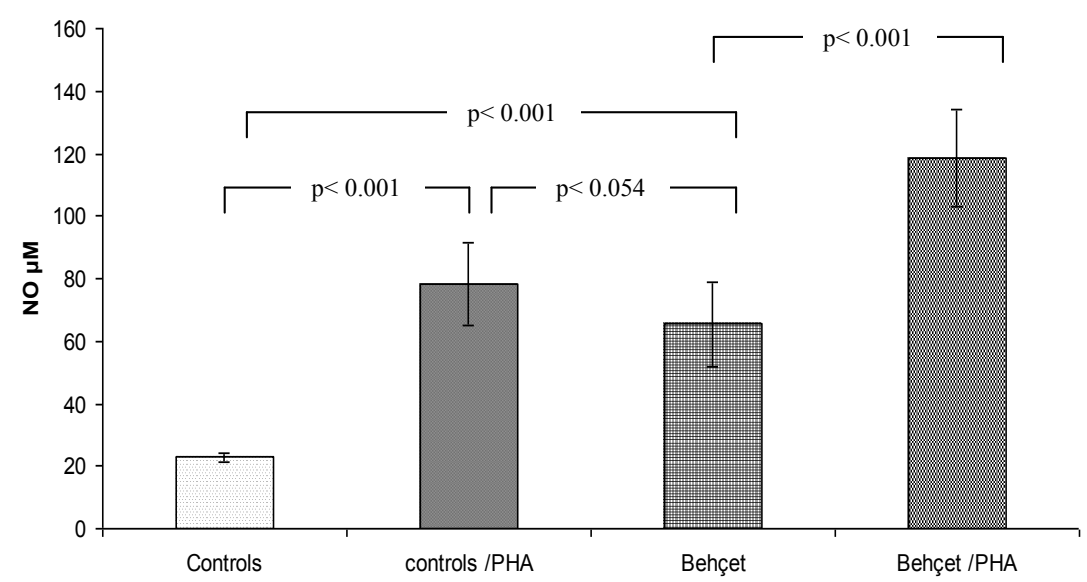

Figure 1 Cytokines and nitric oxide concentration in PBMC supernatants cultures. PBMC $\left(5 \times 10^{6}\right.$ cells $\left./ \mathrm{ml}\right)$ of patients with ABD and healthy controls were cultured with or without $5 \mu \mathrm{g} / \mathrm{ml}$ phytohemagglutnin (PHA) for $20 \mathrm{~h}$. Supernatants were collected and the production level of IL-12 (A) and IL-4 (B) was determined by a sandwich ELISA. Values shown are mean \pm S.D. $p<0.001$ was significantly different from the control value. C. Concentration of nitric oxide in the supernatants of culture of PBMC from patients with Adamantiades-Behçet's disease and healthy controls. Cells were treated with $5 \mu \mathrm{g} / \mathrm{mL}$ of PHA. Supernatants were collected after $20 \mathrm{~h}$ and the nitrite level was determined by modified Griess reaction. The data represent the mean \pm S.D. of cultures. ${ }^{*} p<0.05$. NO levels were significantly different from the control values. 
Quantitative determination of IL-4 in supernatants of ABD patients and normal control's indicated different profiles according to the disease evolution (Figure 1B). Indeed, during the active phase, we observed a higher spontaneous production in ABD patients' PBMC culture supernatants in comparison to the healthy controls (63.1 \pm 37 versus $39.7 \pm 13.1 \mathrm{pg} / \mathrm{mL}, \mathrm{P}<0.05)$. PHA induced a significant increase in the cytokine production in all groups tested. However, IL-4 levels in PBMCs supernatants, after stimulation with PHA $(5 \mu \mathrm{g} / \mathrm{mL})$ were significantly higher in ABD patients compared to the controls $(241.8 \pm 33.5$ versus $131.3 \pm 12.6 \mathrm{pg} / \mathrm{mL}, p<0.001)$ (Figure 1B). In contrast, the preactivated PBMC from controls showed a significant modification in IL-4 production after treatment with PHA at $5 \mu \mathrm{g} / \mathrm{mL}$ compared to $\mathrm{ABD}$ patients without stimulation $(p<0.001)$.

In vitro production of NO during the active stage of $A B D$ $\mathrm{NO}$ measurement in culture supernatants showed that the spontaneous production was higher in ABD PBMC cultures compared to NCs $(65.39 \pm 15.56$ versus $22.84 \pm$ $1.40 \mu \mathrm{M}, p<0.001)$. Further, NO levels increased significantly in all culture supernatants after treatment with PHA $(\mathrm{P}<0.05)$. We noticed that $\mathrm{NO}$ levels in treated PBMC cultures from ABD was higher than in healthy controls $(118.48 \pm 15.49$ versus $78.31 \pm 13.41 \mu \mathrm{M}, p<$ 0.001) (Figure 1C). The preactivated PBMC cultures from NCs treated with PHA did not show any significant difference compared to those from ABD patients without prestimulation $(p=0.054)$.

\section{Flavonoïds did not affect cells viability}

To assess if there is any cytotoxic effect of flavonoïds, we tested cell viability before and after PHA treatment. Viability of cells was about $90 \%$ before and about $70 \%$ after experiments with no differences between flavonoïds-treated and untreated control cells. So flavonoïds were not cytotoxic which is consistent with the previous observations [38].

\section{Flavonoïds modulate IL-12 and IL-4 production in PBMCs} of ABD patients and NCs

To further confirm the enhancement of the production of the cytokines production by flavonoïds and their aptitude to respond to the PHA preactivated PBMC in healthy controls, flavonoïds were added at different doses $5,10,20,30,40$ or $50 \mu \mathrm{g} / \mathrm{mL}$ for 20 hours. The contents of the wells were centrifuged and kept frozen until analyzed. We observed that flavonoïds did not reduce the IL-12 production in the PBMC stimulation by PHA in NCs (Figure 2). No reversal effects were noticed at any flavonoïd concentrations used. (808.57 \pm $123.12 \mathrm{pg} / \mathrm{mL}, 5 \mu \mathrm{g} / \mathrm{mL}$ of flavonoïds) and (1194.87 \pm $53.56 \mathrm{pg} / \mathrm{mL}, 50 \mu \mathrm{g} / \mathrm{mL}$ of flavonoïds) compared to

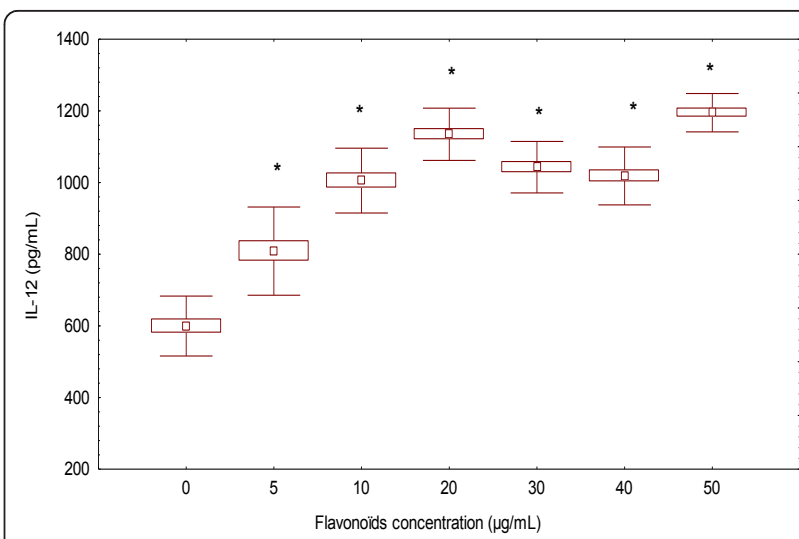

Figure 2 Effect of flavonoïds on IL-12 production by PHA preactivated peripheral blood mononuclear cells. After washing with medium, various concentrations of flavonoïds $(5-50 \mu \mathrm{g} / \mathrm{mL})$ was added for a period of $20 \mathrm{~h}$. Supernatants were collected and the levels of IL-12 were determined by ELISA. The data represent the mean \pm S.D. of triplicate cultures. ${ }^{*} p<0.001, \mathrm{IL}-12$ levels are significantly different from the control value.

control values in the absence of flavonoïds (599.47 \pm $83.56 \mathrm{pg} / \mathrm{mL}$ ).

To test if flavonoïds could induce cytokines modulation in patients without PHA, PBMC from patients were cultured in the presence of different concentrations of flavonoïds $(5-50 \mu \mathrm{g} / \mathrm{mL})$. We observed a significant decrease in IL-12 production in a dose-dependent manner $(p<0.001)$. Interestingly, we have observed that the pre-treatment by flavonoïds inhibited IL-12 production (1048.89 $\pm 128.93 \mathrm{pg} / \mathrm{mL}$ with $10 \mu \mathrm{g} / \mathrm{mL}$ of flavonoïds) and $(778.63 \pm 115.21 \mathrm{pg} / \mathrm{mL}$ with $50 \mu \mathrm{g} / \mathrm{mL}$ of flavonoïds) compared to control values (1221.42 $\pm 36.01 \mathrm{pg} /$ $\mathrm{mL}$ ). (Figure 3 ). There is no statistical differences

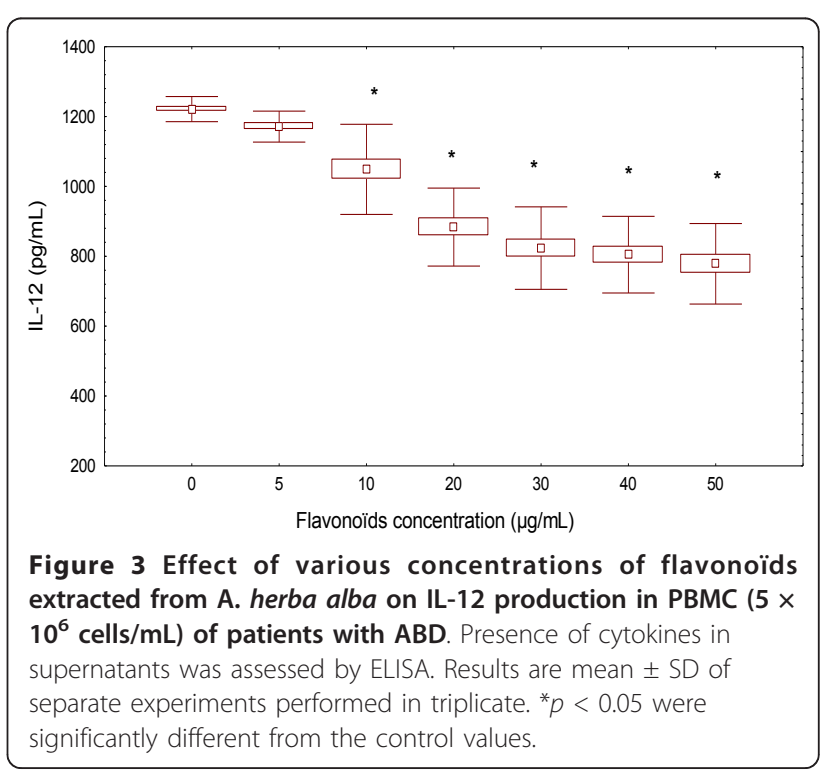




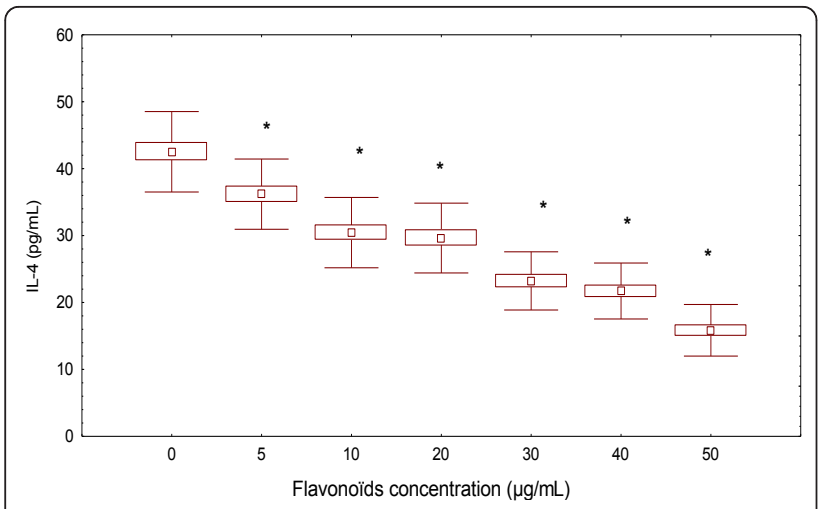

Figure 4 Effect of flavonoïds on IL-4 production in PHAstimulated PBMC of healthy controls. Amounts of IL-4 were measured by ELISA. PBMC $\left(5 \times 10^{6}\right.$ cells $\left./ \mathrm{mL}\right)$ were cultured for $20 \mathrm{~h}$ in the absence or presence of flavonoïds after stimulation with PHA $(5 \mu \mathrm{g} / \mathrm{mL})$. Data represent the mean \pm SD of three independent experiments in each sample compared to controls value and PHAtreated alone value (ANOVA with post-hoc test).

between the doses of flavonoïds $(30,40,50 \mu \mathrm{g} / \mathrm{ml})$ on IL-12 production in PBMC from ABD patients.

Similarly, the amounts of IL-4 released into supernatants of PBMC from controls subjects after pre-stimulation with PHA were determined by ELISA (Figure 4). Treatment of PBMC by different concentrations of flavonoïds inhibited IL-4 production $(73.26 \pm 10 \mathrm{pg} / \mathrm{mL}$, $30 \mu \mathrm{g} / \mathrm{mL}$ of flavonoïds) and $(89.90 \pm 13.25 \mathrm{pg} / \mathrm{mL}, 50$ $\mu \mathrm{g} / \mathrm{mL}$ of flavonoïds) compared to the control values in the absence of flavonoïds $(55.87 \pm 7.98 \mathrm{pg} / \mathrm{mL})$.

In PBMC from $\mathrm{ABD}$ patients, flavonoïds stimulated IL-4 production in a dose-dependent manner and at significantly greater levels compared to the controls (Figure 5). The highest concentration tested $(50 \mu \mathrm{g} / \mathrm{mL})$

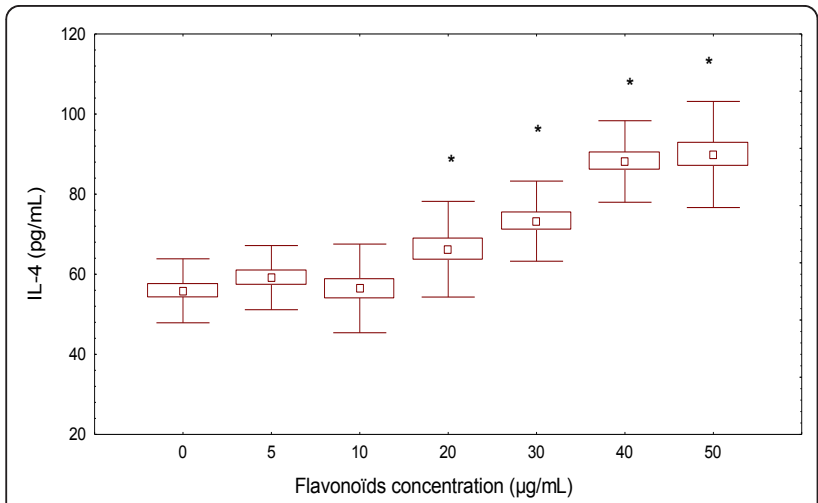

Figure 5 Effect of flavonoïds extract on IL-4 (pg/mL) production in PBMC of ABD patients $(\boldsymbol{n}=\mathbf{2 0})$. Cells $\left(5 \times 10^{6}\right.$ cells $/ \mathrm{mL}$ ) were treated with different concentrations $(5,10,20,30,40$ and $50 \mu \mathrm{g} / \mathrm{mL}$ ) of flavonoïds during $20 \mathrm{~h}$. Presence of cytokines in supernatants were measured by ELISA test. Results are mean \pm SD of seven separate experiments performed in triplicate. ${ }^{*} p<0.05 \mathrm{IL}-4$ levels were significantly different from the control value. exhibited an increased bioactivity. Treatment of flavonoïds induced IL-4 production $(1.116 \pm 0.207 \mathrm{pg} / \mathrm{mL}$ with $10 \mu \mathrm{g} / \mathrm{mL}$ of flavonoïds) and $(0.24 \pm 0.060 \mathrm{pg} / \mathrm{mL}$ with $40 \mu \mathrm{g} / \mathrm{mL}$ of flavonoïds) compared to the control values in the absence of flavonoïds (55. $87 \pm 7.98)$ (Figure 5).

\section{Flavonoïds inhibited nitric oxide production in PBMC from $A B D$ patients}

Next, we examined the effect of flavonoïds on NO production in PBMC from controls subjects stimulated by PHA were tested. NO levels were measured by Griess modified method. We observed that the treatment did not modulate NO production. As shown in Figure 6, flavonoïds had no statistically significant effect (19.21 \pm $2.61 \mu \mathrm{M}$ with $10 \mu \mathrm{g} / \mathrm{mL}$ of flavonoïds and $16.36 \pm 4.25$ $\mu \mathrm{M}$ with $50 \mu \mathrm{g} / \mathrm{mL}$ of flavonoïds). The control values in the absence of flavonoïds being $21.03 \pm 4.31 \mu \mathrm{M}$.

We then tested the inhibitory effect of flavonoïds on $\mathrm{NO}$ production in PBMC from ABD patients (Figure 7). Interestingly, we observed that the treatment with flavonoïds during $20 \mathrm{~h}$ reduced the NO concentration in all cultures supernatants $(\mathrm{p}<0.05)$. This inhibitory effect was in dose-dependent manner $(10 \mu \mathrm{g} / \mathrm{mL}$ and $50 \mu \mathrm{g} /$ $\mathrm{mL}$ ). The corresponding nitrite concentrations assessed were respectively: $36.13 \pm 5.22 \mu \mathrm{M}$ and $20.47 \pm 3.85 \mu \mathrm{M}$

\section{Discussion}

It is currently recognized that Th cells may be divided into several functional subclasses, Th-1, Th-2, Treg, Th17 cells, based on the production profile of cytokines and their effects on cell mediated and humoral immunity. Th-1 cells produce IL-12, IFN- $\gamma$ and enhance cellmediated immunity. Th- 1 cells also can inhibit cell-

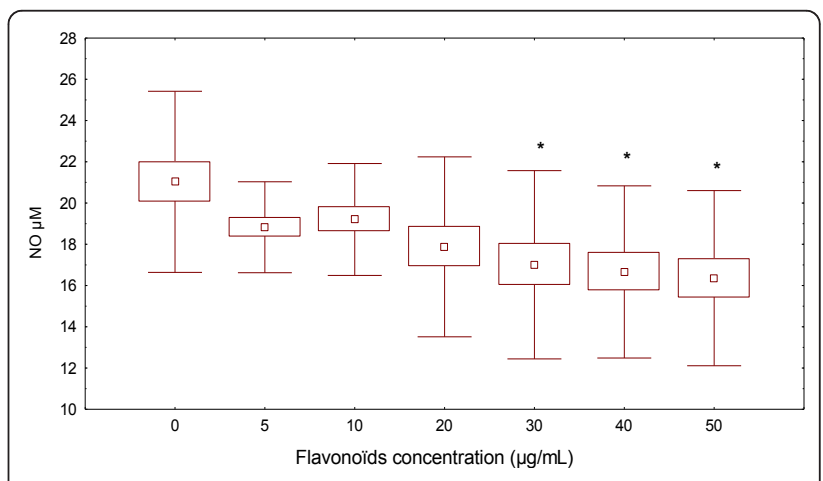

Figure 6 Effect of flavonoïds on nitric oxide production in PHA-stimulated PBMC of healthy controls. PBMC $\left(5 \times 10^{6}\right.$ cells/ $\mathrm{mL}$ ) were stimulated with PHA then cultured with or without flavonoïds $(5,10,30,40$ and $50 \mu \mathrm{g} / \mathrm{mL})$. The cell-free supernatants were collected and NO concentration was determined by Griess modified method. The data represents the mean \pm S.D. of triplicate cultures.* $p<0.05 \mathrm{NO}$ rates was significantly different from the control value (ANOVA with post-hoc test). 


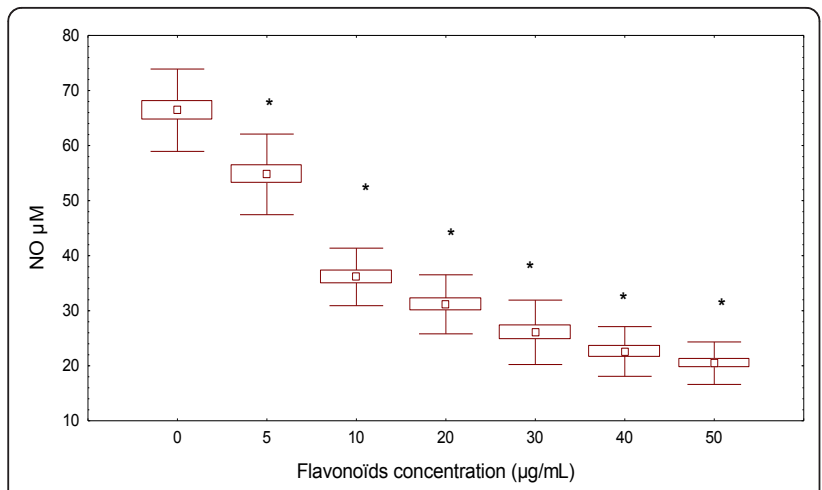

Figure 7 Effect of different concentration of flavonoïds on nitric oxide production by PBMC in patients with ABD

Flavonoïds extracts from A. herba alba are used at the indicated concentrations and compared to the controls. Supernatants were collected to determine the amount of NO. The data represents the mean \pm S.D. of triplicate cultures. ${ }^{*} p<0.05$ was significantly different from the control value (absence of flavonoïds).

mediated immunologic activities. In our studies, we showed a significant increase of IL12 levels in supernatant of PBMC culture from ABD patients. IL-12 is an immunoregulatory cytokine regulating cell-mediated immune response by inducing the differentiation of uncommitted CD4 Th cells towards type 1 phenotype and a potent cofactor for stimulating the proliferation of differentiated Th1 cells and IFN- $\gamma$ synthesis [39]. In our study, we confirmed that IL-12 production by PBMC is significantly higher in $\mathrm{ABD}$ patients compared to healthy controls suggesting that IL-12 is involved in the pathogenesis of $\mathrm{ABD}$.

Moreover, Th- 2 cells produce IL-4, IL-5 and IL-13 and upregulate humoral immunity [40]. In the current study, higher concentrations of IL-4 were also observed in ABD patients. This Th- 2 derived cytokine is primarily involved in the activation of $\mathrm{B}$ cells, the promotion of growth and the survival of $\mathrm{T}$ cells, the inhibition of macrophage and the activation and suppression of Th-1 cells. Recent studies have showed that IL- 4 and IL-12 play a significant role in the regulation of the immune responses by their reciprocal antagonistic mechanisms.

We found that the concentration of nitric oxide in the PBMC supernatant were significantly elevated in ABD patients compared to the healthy controls. Here, we postulated that NO could play an important role in the inflammatory process associated with AdamantiadesBehçet's disease [41]. Several studies have suggested that the overexpression of either inducible NO and proinflammatory cytokines might be intimately involved in the pathogenesis and the evolution of ABD [12,42]. An increase in the concentration of NO during the $\mathrm{ABD}$ was reported in several studies and this in both the sera of patients [43] and also in the synovial liquid [44]. The presence of $\mathrm{NO}$ was also observed in uveitis associated with $\mathrm{ABD}$ in particular in the aqueous humour $[45,46]$. The increase of NO levels in all cases was correlated with the active stage of the ABD.

Stimulation of PBMC cultures from ABD patients with PHA induced an increase of IL-12, IL-4 and NO production. We suggest that the increase of the IL-4 levels in ABD patients after PHA stimulation is probably related to the presence of some factors induced by PHA in PBMC cultures acting on Th-2 cells subset. This purpose remains to be clarified in adequate experiment model. Regarding to the comparison between the production of IL-4 by PHA in healthy controls and ABD patients, the difference observed is probably in relation with the difference in the initial activation level of PBMC state in the two groups of subjects.

Moreover, the increase IL-12 levels after stimulation with PHA on PBMC from ABD patients is related to the production of IFN- $\gamma$ by Th1 cells. This is consistent with the fact that IFN- $\gamma$ is known to strongly activate the monocyte/Macrophage system which is the major source of IL-12. Several studies have reported that NO is upregulated by IFN- $\gamma$. Recently, our group showed the pivotal role of IFN- $\gamma$ in pathophysiology of ABD particularly via the NO pathway [46].

There is an increasing interest in herbal medications especially for diseases like ABD $[47,48]$. The present study demonstrates that flavonoïds extracts from A. herba alba highly inhibited the production of the proinflammatory cytokine IL-12 in ABD patients PBMC. The mechanism involved remains to be clarified. Furthermore, in our study we reported that the inhibitory effect on IL-12 production was not due to the toxicity of flavonoïds on PBMC. In fact, in our culture system the use of a high flavonoïds concentration at $50 \mathrm{pg} / \mathrm{ml}$ after $20 \mathrm{~h}$ incubation yielded almost $70 \%$ viable cells. It has been shown that increased IL-12 levels and Th1 cytokines did occur in patients with $\mathrm{ABD}$ and have been associated with the pathogenesis.

In contrast to IL-12, we found that flavonoïds promoted a significant increase in IL- 4 produced. IL- 4 is one of the Th- 2 cytokines which has been associated with an improvement in the inflammatory diseases [49]. In the study reported by Koteswara Rao et al., [50], flavonoïds have been shown to inhibit extensively the proinflammatory cytokines like TNF- $\alpha$, IL-12 in a dose-dependent manner. These authors suggested that flavonoïds mediate differentiation from Th-1 to Th-2 cell types and our results are consistent with this study. We also suggest the role of other cytokines or immunoregulatory mediators in the differential regulation of IL-4 (upregulated) and IL-12 (downregulated). These suggestions remain to be clarified in an adequate experimental model. However, it is possible that the inhibition of IL- 12 production may be partially mediated by the 
action of flavonoids through IL-4 induction as both IL-4 and IL-12 have shown to have antagonism effects. IL-4 exerts strong inhibition on Th1-mediated inflammatory processes involving the regulation of the synthesis of inflammatory cytokines (IL-2 TNF- $\alpha$, IL- $1 \beta$ ) and chemokines (CXCL8, CXCL10, CCL2). The effect of flavonoïds on cytokine modulation constitutes a very exciting finding for their possible therapeutic applications.

For the role of NO, we suggest that flavonoïds regulate not only the balance Th1/Th2 towards Th- 2 but also NO production. The results presented here show that flavonoïds isolated from A. herba halba, affect also NO production in PBMC isolated from patients with ABD in a dose-dependent manner. The inhibitory activity could be resulted from the inhibition of iNOS expression and/or its activity.

\section{Conclusion}

We report here the evidence that the Th-1 cytokines (IL-12) and NO are involved in the pathogenesis of ABD. Our limited follow-up study also suggests that flavonoïds extracts from A. herba alba have an effect on the inhibition and the stimulation of the production of IL-12 and of IL-4, respectively. This constitutes a way to switch the immune response from Th-1 to Th2. Further investigations will focus on the assessment of the biological activity of this extract in vivo and on the chemical identification of the active components responsible for the anti-inflammatory activity. The knowledge of the role of flavonoïds in the immunomodulatory mechanisms in $\mathrm{ABD}$ is a promising area for the development of new natural's agents for the treatment of the disease and other immune-mediated diseases.

\section{Abbreviations}

ABD: Adamantiades-Behçet's disease; Th: T helper cell; IL: interleukin: IFN-ץ: interferon- $\gamma$; NO: Nitric oxide; PBMC: peripheral blood mononuclear cells: NO3-: nitrate; NO2-: nitrite; NOS2: nitric oxide synthase-2.

\section{Acknowledgements}

The authors would like to thank all patients and voluntary participants at this study. This work was supported by a grant form the ANDRS (National Agency for Scientific Development and Research in Health) Project No.1601/ 09/2009).

We are grateful to Dr. M.A. Ayoube, Western Australian Institute for Medical Research, for expert preparation of the manuscript.

\footnotetext{
Author details

'Laboratoire de Biologie Cellulaire et Moléculaire (LBCM), FSB, USTHB. Université de Bab-Ezzouar. BP32, 16111. Algiers, Algeria. ${ }^{2}$ Département de Biologie, Faculté des sciences, université de Boumerdes, Algeria. ${ }^{3}$ Service de médecine Interne, CHU Mustapha Bacha. Algiers, Algeria. ${ }^{4}$ Service d'ophtalmologie, CHU Bab El Oued. Algiers. Algeria. ${ }^{5}$ Laboratoire d'immunologie. Centre Hospitalier Universitaire. Brest, France.
}

\section{Authors' contributions}

MD carried out the experimental work, collected and interpreted the data. $\mathrm{BH}$ and $\mathrm{ML}$ carried out most of the in vivo experiments. TM and OF recruited the ABD patient's and volunteers and organized the study. BT carried out the experimental work. PY participated in the design and wrote the manuscript. TC contributed to planning of the design and execution of the project and wrote the ethic's committee application and drafting the manuscript. All authors read and approved the final manuscript.

\section{Competing interests}

The authors declare that they have no competing interests.

Received: 16 March 2011 Accepted: 21 November 2011 Published: 21 November 2011

\section{References}

1. Amoura Z, Guillaume M, Caillat-Zucman S, Wechsler B, Piette JC: Pathophysiology of Behçet's disease. La revue de medicine interne 2006, 27:843-853.

2. Yazici H, Fresko I, Yurdakul S: Behcet's syndrome: disease manifestations, management, and advances in treatment. Nature clinical practice 2007, 3:148-155.

3. Hamzaoui K, Hamzaoul A, Guemira F, Bessioul M, Hamza M, Ayed K: Cytokine profile in Behçet's disease patients. Scand J Rheumatol 2002, 31:205-210.

4. Sugi-lkai N, Nakazawa M, Nakamura S, Ohno S, Minami M: Increased frequencies of interleukin-2- and interferon-gamma producing $T$ cells in patients with active Behçet's disease. Invest Ophthalmol Vis Sci 1998, 39:996-1004.

5. Saruhan-Direskeneli G, Yentür SP, Akman-Demir G, Ișik N, Serdaroğlu P: Cytokines and chemokines in neuro-Behçet's disease compared to multiple sclerosis and other neurological diseases. J Neuroimmunol 2003, 145:127-134

6. Imamura Y, Kurokawa MS, Yoshikawa H, Nara K, Takada E, Masuda C, Tsukikawa S, Ozaki S, Matsuda T, Suzuki N: Involvement of Th1 cells and heat shock protein 60 in the pathogenesis of intestinal Behçet's disease. Clin Exp Immunol 2005, 139:371-378.

7. Frassanito MA, Dammacco R, Cafforio P, Dammacco F: Th1 polarization of the immune response in Behçet's disease: a putative pathogenetic role of interleukin-12. Arthritis Rheum 1999, 42:1967-1974.

8. Raziuddin S, Al-Dalaan A, Bahabri S, Siraj AK, Al-Sedairy S: Divergent cytokine production profile in Behçet's disease. Altered Th1/Th2 cell cytokine pattern. J Rheumatol 1998, 25:329-33.

9. Buney S, Caufield JL, Niles JC, Wishnok JS, Tannbaum SR: The Chemistry of DNA damage from nitric oxide and peroxynitrite. Mutation Res 1999, 424:37-49.

10. Steffen $Y$, Jung $T$, Klotz LO, Schewe T, Grune T, Sies H: Protein modification elicited by oxidized low-density lipoprotein (LDL) in endothelial cells. Protection by (-)-epicatechin. Free Radic Biol Med 2007, 42:955-70.

11. Beckman JS, Koppenol WH: Nitric oxide, superoxide, and peroxynitrite: The good, the bad, and ugly. Amer J Physiol 1996, 271:C1424-C1437.

12. Yu L, Gengro PE, Niedrberger M, Burk TJ, Schrier RW: Nitric oxide: A mediator in rat tubular hypoxia/reoxygenation injury. Proceeding of the Natural Academy of Science USA 1994, 91:1691-1695.

13. Rafa H, Abdelouaheb K, Belkhelfa M, Medjeber O, Saoula H, Zeriguine R, Nakmouche M, Touil-Boukoffa C: Nitric oxide modulation by retinoic acid, IL-17A and TNF-a in PBMC and colonic mucosa cultures from Algerian patients with inflammatory bowel disease. Cytokine 2010, 52:17-34.

14. Guenane H, Hartani D, Chachoua L, Lahlou-Boukoffa OS, Mazari F, TouilBoukoffa C: Production des cytokines Th1/Th2 et du monoxyde d'azote au cours de l'uvéite Behçet et de I'uvéite idiopathique. J Fr Ophtalmol 2006, 29:146-152.

15. Nathan C: NO as a secretory product of mammalian cells. J FASEB 1992, 6:3051-3064

16. Hobbs AJ, Higgs A, Moncada S: Inhibition of nitric oxide synthase as a potential, therapeutic target. Ann Res Pharmacol Toxicol 1999, 39:191-220.

17. Nakagawa T, Yokozawa T: Direct scavenging of nitric oxide by green tea. Food Chem Toxicol 2002, 40:1745-1750.

18. Shen SC, Lee WR, Lin HY, Huang HC, Ko Ch, Yang LL, Chen YC: In vitro and in vivo inhibitory activities of rutin, wogonin, and quercetin on lipopolysaccharide-induced nitric oxide and prostaglandin $\mathrm{E}(2)$ production. Eur J Pharmacol 2002, 446:187-194.

19. Vernin G, Merad O, Vernin GMF, Zamkotsian RM, Parkanyi C: GC-MS analysis of Artemisia herba-alba Asso essential oils from Algeria. Dev Food Sci 1995, 3A:147-205. 
20. Ahmed AA, Abou El-Ela M, Jakupovic J, Seif El-Din AA, Sabri N: Eudesmanolides and other constituents from Atemisia herba alba. Phytochem 1990, 29:3661-3663.

21. Tang $H Q, H u J$, Yang $L$, Tan RX: Terpenoids and flavonoids from Artemisia species. Planta Med 2000, 66:391-393.

22. Tan RX, Tang HQ, Hu J, Shuai B: Lignans and sesquiterpene lactones from Artemisia Sieversiana and Inula racemosa. Phytochem 1998, 49:157-161.

23. Jiangsu New Medicine College: A Comprehensive Dictionary of Traditional Chinese Medicine. Shanghai Science and Technology Press, Shanghai 1977, 627.

24. El-Thaher TS, Matalka KZ, Taha HA, Badwan AA: Ferula harmonis 'zallouh' and enhancing erectile function in rats: efficacy and toxicity study. Int J Impot Res 2001, 13:247-251.

25. Davis SR, Dalais FS, Simpson ER, Murkies AL: Phytoestrogens in health and disease. Recent Prog Horm Res 1999, 54:185-211.

26. Singh MM, Agnihotri A, Garg SN, Agarwal SK, Gupta DN, Keshri G, Kamboj VP: Antifertility and hormonal properties of certain carotane sesquiterpenes of Ferula jaeschkeana. Planta Med 1988, 54:492-494.

27. Saleh NAM, El- Negoumy SI, Abd-All MF, Abou- Zaid MM, Dellamonica G, Chopin J: Flavonoid glycosides of Artemisia monosperma and A. herba alba. Phytochem 1985, 24:201-203.

28. Saleh NAM, El-Negoumy SI, Abou-Zaid MM: Flavonoids of Artemisia judaica, A. monosperma and Artemisia herba-alba. Phytochem 1987, 26:3059-3064.

29. Erlund I: Review of the flavonoïds quercetin, hesperetin, and naringenin. Dietary sources, bioactivities, bioavailability and epidemiology. Nutr Res 2004, 24:851-874.

30. Nair MP, Mahajan S, Reynolds $J$, Aalinkeel R, Nair H, Schwartz SA, Kandaswami C: The flavonoid quercetin inhibits proinflammatory cytokine (Tumor necrosis factor alpha) gene expression in normal peripheral mononuclear cells via modulation of the NF-kB system. Clin Vaccine Immunol 2006, 13:319-328.

31. Harborne JB, Williams CA: Advances in flavonoids research since 1992. Phytochem 2000, 55:481-504.

32. Hsu CL, Yen GC: Phenolic compounds: Evidence for inhibitory effects against obesity and their underlying molecular signalling mechanisms. Mol Nutr Food Res 2008, 52:53-61.

33. Peterson J, Dwyer J: Flavonoids: Dietary occurrence and biochemical activity. Nutrition Res 1998, 18:1995-2018.

34. Zhang J, Shen Q, Lu JC, Li JY, Liu WY, Yang JJ, Li J, Xiao K: Phenolic compounds from the leaves of Cyclocarya paliurus (Batal.) Iljinskaja and their inhibitory activity against PTP1B. Food Chem 2010, 119:1491-1496.

35. International Study Group for Behçet's disease: Criteria for diagnosis of Behçet's disease. Lancet 1990, 335:1078-1080.

36. Paris $\mathrm{R}$, Nothis A: Plantes médicinales de la nouvelle Calédonie./2, Etude particulière de plantes à dérivés polyphénoliques. Plant Med Phytothérapie 1970, 4:63-74.

37. Amri M, Aït Aïssa S, Belguendouz H, Mezioug D, Touil-Boukoffa C: In Vitro Antihydatic Action of Gamma Interferon (IFN) is Dependent of Nitric Oxide (NO) pathway. J Interferon Cytokine Res 2007, 22:781-787.

38. Krakauer $T$, Li BQ, Young $H A$ : The favonoid baicalin inhibits superantigeninduced inflammatory cytokines and chemokines. FEBS Letters 2001, 500:52-55.

39. Trinchieri G: Interleukin 12 and its role in the generation of $\mathrm{TH} 1$ cells. Immunol Today 1993, 14:335-338.

40. Elenkov IJ, Chrousos GP: Stress hormones, Th1/Th2 patterns, pro/antiinflammatory cytokines and susceptibility to disease. Trends Endocrinol Metab 1999, 10:359-68.

41. Evereklioglu C, Turkoz Y, Er H, Inaloz HS, Ozbek E, Cekmen M: Increased serum nitric oxide production in patients with Behçet's disease: is it a new activity marker? J Am Acad Dermatol 2002, 46:50-54.

42. Belguendouz H, Messaoudene D, Hartani D, Chachoua L, Ahmedi ML, Lahmar-Belguendouz K, Lahlou-Boukoffa OS, Touil-Boukoffa C: Effet de la corticothérapie sur la production des interleukines 8,12 et du monoxyde d'azote au cours des uvéites « Behçet » et « idiopathique ». J Fr Ophtalmol 2008, 31:387-395.

43. Evereklioglu C, Er H, Turkoz Y, Cekmen M: Serum levels of TNF-alpha, sIL$2 \mathrm{R}, \mathrm{IL}-6$, and IL-8 are increased and associated with elevated lipid peroxidation in patients with Behçet's disease. Mediators Inflamm 2002, 11:87-93.
44. Duygulu F, Evereklioglu C, Calis M, Borlu M, Cekmen M, Ascioglu O: Synovial nitric oxide concentrations are increased and correlated with serum levels in patients with active Behcet's disease: a pilot study. Clin Rheumatol 2005, 24:324-30.

45. Yilmaz G, Sizmaz S, Yilmaz ED, Duman S, Aydin P: Aqueous humor nitric oxide levels in patients with Behçet disease. Retina 2002, 22:330-5.

46. Belguendouz H, Messaoudene D, Lahmar K, Ahmedi L, Medjeber O, Hartani D, Lahlou-Boukoffa O, Touil-Boukoffa C: Interferon- $\gamma$ and Nitric Oxide Production During Behçet Uveitis: Immunomodulatory Effect of Interleukin-10. J interferon Cytokine Res 2011, 31:643-51.

47. Mi-Sun K, Hwan-Suck C, Jun-Gyoung L, Woon Ki L, Chung-Yeon H, EonJeong L, Kwang-Ho C, Dac-Han W, Hyung-Min K: Inhibition of cytokine production by the traditional oriental medicine, 'Gamcho-Sasim-Tang' in mitogen-stimulated peripheral blood mononuclear cells from Adamantiades-Behçet's patients. J Ethnopharmacol 2002, 83:123/-128.

48. Seonghyang S, Dongsik B, Seung Ihm L, Young Ae K, Eun-So L, Jee Yong H, Jang Hyun K, Suh Young C, Sungnack L: Combined treatment with colchicine and Herba Taraxaci (arazacum mongolicum Hand.-Mazz.) attenuates Behçet's disease-like symptoms in mice and influences the expressions of cytokines. Interl Immunopharmacol 2003, 3:713-721.

49. Noben-Trauth N, Hu-Li J, Paul WE: IL-4 secreted from individual naive CD4 + T cells acts in an autocrine manner to induce Th2 differentiation. Eur $J$ Immunol 2002, 32:1428-33.

50. Koteswara Rao Y, Fang SH, Tzeng YM: Anti-inflammatory activities of flavonoids isolated from Caesalpinia pulcherrima. J Ethnopharmacol 2005, 100:249-253

doi:10.1186/1476-9255-8-35

Cite this article as: Messaoudene et al: Ex vivo effects of flavonoïds extracted from Artemisia herba alba on cytokines and nitric oxide production in Algerian patients with Adamantiades-Behçet's disease. Journal of Inflammation 2011 8:35.

\section{Submit your next manuscript to BioMed Central and take full advantage of:}

- Convenient online submission

- Thorough peer review

- No space constraints or color figure charges

- Immediate publication on acceptance

- Inclusion in PubMed, CAS, Scopus and Google Scholar

- Research which is freely available for redistribution

Submit your manuscript at www.biomedcentral.com/submit
C) Biomed Central 